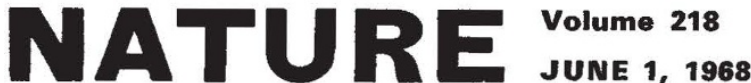

\section{All Change at the Museum}

SIR JoHN WoLFENDEN as chairman of the University Grants Committee may not have agreed with the Government's policy of making the committee more a government department than an autonomous advisory body, but he bent to the civil service wind and neither made public the advice he gave nor commented on the Government's decisions. How will he fare in the face of the storm that is surely brewing between the trustees of the British Museum, now led more vociferously than ever by the new chairman Lord Eccles, and the British Government, which Mr Gordon Walker seemed to have committed, last year, to finding an alternative site to Bloomsbury for a new British Museum library ?

Things seem to have been going Lord Eccles's way lately. He seems confident that the Dainton Committee on the future of librarians will recognize what he calls the overwhelming evidence for the Bloomsbury site. The departure of Mr Gordon Walker must be more gratifying to the trustees than to almost anybody else; it must almost seem something of a victory. And now he and the trustees have managed to persuade Sir John to spend his last five years in public office as director of the museum. Sir John, who freely admits that he has no experience of museums, does know his way about Whitehall and the universities, and that should provide a double bonus for the trustees. He may well help them get more money, but he is unlikely to challenge their views or have any fixed opinions on the future of the museum. Indeed, with Lord Eccles behaving a little like director as well as chairman of the trustees, and with Miss M. Webb, who now runs the National Reference Library of Science and Invention, appointed as assistant director, presumably to oversee the library, it is to be hoped that there will be some decisions left for Sir John to make.

But if his function is to look after external relations at the museum, everybody may be pleased-even, perhaps, the Government. Sir John is an outsider to the museum service, and in the event of a real showdown with the trustees over the site for the new library, he may well be less outspokenly an awkward customer then. Sir Frank Francis, the retiring director, and an old museum man, has done nothing to hide his dislike of $\mathrm{Mr}$ Gordon Walker's decision. In the circumstances, it is predictable that the Museums Association has taken umbrage that a professional was not appointed, but its argument is not worth much. For one thing Sir John will be dependent on his colleagues for advice. In any case, professional museum curators had their chance, and according to Lord Eccles no one of sufficient calibre applied. But it is also plain that if the long-term interests of the museum and-more particularly-its users are to be safeguarded in the years ahead, the skills of curators will not be nearly sufficient.

Although Sir John Wolfenden may often find himself the prisoner of events at the museum, the same need not be true of his successor at the University Grants Committee. Much will depend on the conception of the commission's role which the Department of Education and Science wishes to perpetuate. Sir John Wolfenden may have been unlucky to have superintended over the commission during the period in which its independence was eroded by the pressure of the sheer scale on which universities are now financed. It may now be too late to return to that old liberal notion that the UGC could act as a cushion between the Government and the universities, taking public money and then sharing it out among the universities as it deemed best. Not merely is the scale of the operation now so large that a chaste convention like this must prove unworkable, but there are also difficulties in making sure that a thoroughly autonomous university system can be properly articulated with other parts of the educational system. In the process of transforming the UGC into a kind of extra-mural branch of the Department of Education and Science - for the best of reasons-the authorities have taken away one of the great virtues of the system as it used to be. The UGC is no longer able to speak up for the universities with a clear voice when it seems as if some issue of principle is threatened. The result is that the interaction between the universities and the Government has become dangerously one-sided.

This is the consideration which should weigh most heavily with the Minister of Education in his search for a successor to Sir John Wolfenden. How is it possible to keep a proper eye on the way in which the universities ask for money, and then spend it, without reducing them to the status of mute pensioners of the public purse? There is at least a case for asking whether the best solution is not the one that is bound to seem the most radical of all-the abolition of the UGC as an independent entity. The advantage is that people would at least know where they stand. In particular, it would then be much easier for the Committee of Vice-Chancellors to set itself up as an independent commentator on government policy on higher education. In the process, of course, it would find itself being transformed into the instrument for formulating the demands of the universities for financial support-and it would probably find itself less dependent on rules of thumb than the UGC has been in recent years. In the long run, it could become a much more acceptable instrument of rationalization within the universities than ever the UGC could be. 